\title{
Reflections on Ulrich Beck's legacy in the field of youth transitions and employment.
}

Karen Evans, UCL Institute of Education

In Beck's (1992) outline of an emergent 'risk society' the emphasis was placed on the increased uncertainty and unpredictability of the individual's life course. The person learns to 'conceive of him or herself as the centre of action, as the planning office with respect to his/her own biography' (p.135) trying to minimise risk and maximise personal opportunities. Beck believed that individualisation heralded the dissolution of factors traditionally seen as determining many aspects of life in industrialised societies - class culture and consciousness, gender and family roles. In England, this work was paralleled by Anthony Giddens' more critical accounts of reflexive modernisation (1991, 1998). These bold assertions elicited an immediate response from scholars and researchers in the interdisciplinary fields of life course studies and youth transitions, particularly among those focusing on changing patterns of experience in the education to work transitions of young adults. Furlong and Cartmel (1997) for example, argued that these accounts of individualisation represented an epistemological fallacy. They claimed that the social world has only come to be regarded as unpredictable and filled with risks that can only be negotiated on an individual level, disguising the reality that structural forces operate as powerfully as ever and the chains of human interdependence remain intact.

Beck offered spirited responses to such critiques, which he considered fundamentally to misinterpret his work. In the collection of translated essays brought together in the book Democracy without Enemies (1998) he asserted that 'individualisation does not mean a lot of things that many people wish it meant in order to be able to refute it more easily' (p.33). In an exposition on the situation of contemporary youth ('Freedom's Children') he developed his argument that young people are compelled to individualise their life course and that institutions play a key role in forcing a collective experience of 'programmed individualisation'. In this context, the reproduction of inequalities in educational and employment trajectories and the continued predominance of standard pathways from education into work were held by Beck $(1998,2001)$ to reflect a process of 'self-normalisation'. This was arguably the least developed aspect of his account of individualisation, which offered 
no more than a series of theoretical sketches that invited development and contestation in 'empirical encounters' of various kinds. In my own work, for example, the comparative analysis of data generated by empirical encounters in contrasting socio-economic and labour market settings in England and Germany with samples of young adults entering employment, or experiencing periods of unemployment and underemployment, has generated an extended dialogue between ideas and evidence to shed light on the beliefs young people have about their abilities to control their lives and the social processes that lead to the greatest demands being placed on the least powerfully positioned in changing social landscapes (Evans 2002, 2009).

Beck's sketch of individualisation as a process to which we are condemned in late modernity has thus both stimulated empirical investigations into the situation of young adults experiencing prolonged transitions into employment and has provoked responses that have re-invigorated the structure-agency debate. The institutionalised individualisation processes of late modernity are shown not only to have structural foundations but are also revealed to be profoundly relational, as human agency is increasingly recognised to be distributed across people and their relationships to each other, biographically produced and temporally embedded (Ketokivi, K. and Meskur, M. 2015). To build on Beck's legacy now is to examine more closely the actualities of young people's working lives under harsh economic conditions, with renewed attention to what collective experiences of individualisation mean for personal strivings in youth and the inter-personal connections that young people forge in the social world and through the practices of everyday life.

\section{References:}

Beck, U. (1992) Risk Society: Towards a new modernity. London: Sage.

Beck, U. (1998) Democracy without Enemies. Cambridge: Polity Press. 
Beck, U. (2001) Living your own life in a runaway world: Individualisation, Globalisation and Politics. In Hutton, W. and Giddens. A. On the Edge: Living with Global Capitalism. London: Vintage.

Evans, K. (2002) 'Taking Control of their Lives? Journal of Youth Studies, 5, 3, 245 269

Evans, K. (2009) Learning, Work and Social Responsibility. Challenges for Lifelong Learning in a Global Age. Dordrecht: Springer.

Furlong, A. and Cartmel, F. (1997). Young People and Social Change? Individualisation and risk in late modernity. Buckingham: Open University Press.

Giddens, A. (1991). Modernity and Self Identity. Cambridge: Polity.

Giddens, A. (1998). The third Way: The renewal of social democracy. Cambridge: Polity.

Ketokivi, K. and Meskur, M. (2015) The dilemma of the capable actor and the case of disrupted lives' Contemporary Social Science 10, 1, 39-51. 